\title{
LONGITUDINAL VARIABILITY IN HYDROCHEMISTRY AND ZOOPLANKTON COMMUNITY OF A LARGE RIVER: A LAGRANGIAN-BASED APPROACH
}

\author{
I. BERTANI ${ }^{\mathrm{a}, \mathrm{b}}$, M. DEL LONGO ${ }^{\mathrm{c}}$, S. PECORA ${ }^{\mathrm{c}}$ AND G. ROSSETTI ${ }^{\mathrm{b} *}$ \\ ${ }^{a}$ University of Michigan, Water Center, Graham Sustainability Institute, Ann Arbor, Michigan, United States \\ ${ }^{\mathrm{b}}$ University of Parma, Department of Life Sciences, Parma, Italy \\ ${ }^{\mathrm{c}}$ Emilia-Romagna Environmental Protection Agency, Hydro-Meteo-Climate Service, Parma, Italy
}

\begin{abstract}
The variability in water quality and zooplankton community structure during downstream transport was investigated in the Po river (Italy) using for the first time a Lagrangian sampling approach. Two surveys were conducted, one in spring under relatively high discharge levels, and one at low flows in summer. Twelve stations along a 332-km stretch of the river's lowland reach and four major tributaries were sampled. A hydrodynamic modelling system was used to determine water transport time along the river, with a satisfying fit between simulated and observed discharge values. No clear downstream trend in phosphorus and nitrogen concentrations was found. Conversely, a marked longitudinal decrease in dissolved silica supports the hypothesis of increasing downstream silica limitation during the phytoplankton growing season.

In spring, at low residence time, no apparent plankton growth was observed during downstream transport. In summer, higher temperatures and lower turbulence and turbidity associated with longer residence time stimulated algal growth and in-stream reproduction of fast-growing rotifer taxa, with the gradual downstream development of a truly potamal assemblage and the increase of the ratio of euplanktonic to littoral/epibenthic rotifer taxa. Crustacean zooplankton density was generally low. The importance of biotic interactions within the zooplankton in driving community abundance and composition appeared to increase in the downstream direction, paralleled by a decrease in the influence of physical forcing. Tributary influence was especially evident where severe anthropogenic alterations of river hydrology and trophic status resulted in enhanced plankton growth, ultimately affecting zooplankton structure in the main river. Copyright (C) 2016 John Wiley \& Sons, Ltd.
\end{abstract}

KEY WORDS: Po river; Italy; hydrodynamic forecasting model; space-time variability; hydrochemistry; potamoplankton; community dynamics

Received 16 September 2015; Revised 24 February 2016; Accepted 04 March 2016

\section{INTRODUCTION}

The vast majority of field studies investigating plankton ecology in rivers has generally adopted an Eulerian reference frame, which is based on measuring the flux of objects through or within a spatially bounded area (Doyle and Ensign, 2009). These surveys rely on a traditional sampling design, involving the collection of samples at one or more stations at fixed time intervals, without accounting for water travel time from one station to the next.

An alternative approach is to virtually follow a water parcel as it is advectively transported downstream (Lagrangian reference frame). This method has been used to describe longitudinal changes in water quality and transformation of nutrients and contaminants (Brown et al., 2009; Deutsch et al., 2009; Volkmar et al., 2011; Writer et al., 2011; Coupe et al., 2013) and plankton communities (Weitere and Arndt, 2003; Quiel et al., 2011) in different rivers, as hydrochemical

*Correspondence to: G. Rossetti, University of Parma, Department of Life Sciences, Parco Area delle Scienze 11A, 43124 Parma, Italy.

E-mail: giampaolo.rossetti@unipr.it and biological processes occurring during downstream transport can be studied in a more direct way, and apparent plankton growth rates can be estimated.

Relatively few studies have used a Lagrangian approach to investigate the dynamics of the metazoan component of river plankton, mostly in Central and Eastern Europe (de Ruyter van Steveninck et al., 1992; Welker and Walz, 1998; Ietswaart et al., 1999; Zimmermann-Timm et al., 2007; Scherwass et al., 2010; Gruberts et al., 2012; Napiórkowski and Napiórkowska, 2013; Gruberts and Paidere, 2014; Hardenbicker et al., 2015). Most of these studies showed the occurrence of downstream changes in zooplankton abundance and composition in large lowland rivers. These changes have usually been associated with the longer time available to grow and reproduce, although contrasting patterns may emerge as a result of different hydrological conditions, length of the considered river segment, grazing pressure from benthic filter feeders, time of the year and connectivity of the main river channel to the flood plain (de Ruyter van Steveninck et al., 1992; Welker 
Table I. Sampling sites and schedule of the Lagrangian surveys. For abbreviations of sampling stations see caption of Figure 1

\begin{tabular}{|c|c|c|c|c|}
\hline Sampling station & Date of sampling & Hour of sampling & Date of sampling & Hour of sampling \\
\hline REA_01 & May 26, 2010 & 09:00 & August 19, 2011 & $07: 30$ \\
\hline $\mathrm{TIC}^{-}$ & May 26, 2010 & $11: 30$ & August 19, 2011 & $10: 30$ \\
\hline POR_02 & May 26, 2010 & $15: 40$ & August 19, 2011 & $19: 56$ \\
\hline COR_03 & May 26, 2010 & $22: 45$ & August 20, 2011 & $07: 17$ \\
\hline MOR_04 & May 27, 2010 & 06:00 & August 20, 2011 & $22: 49$ \\
\hline $\mathrm{ADD}$ & May 27, 2010 & $09: 30$ & August 21, 2011 & $10: 30$ \\
\hline CRE_05 & May 27, 2010 & $19: 15$ & August 22, 2011 & $21: 06$ \\
\hline STA_06 & May 28, 2010 & 03:00 & August 23, 2011 & $10: 33$ \\
\hline VIA_07 & May 28, 2010 & $13: 50$ & August 24, 2011 & $01: 23$ \\
\hline RIV_08 & May 28, 2010 & $18: 10$ & August 24, 2011 & $08: 11$ \\
\hline $\mathrm{OGL}^{-}$ & May 28, 2010 & $20: 40$ & August 24, 2011 & $10: 40$ \\
\hline BRG_09 & May 28, 2010 & $23: 10$ & August 24, 2011 & $15: 10$ \\
\hline $\mathrm{MIN}^{-}$ & May 29, 2010 & 09:00 & August 24, 2011 & $17: 30$ \\
\hline SAC_10 & May 29, 2010 & $05: 45$ & August 25, 2011 & $00: 38$ \\
\hline PON_11 & May 30, 2010 & $00: 50$ & August 26, 2011 & $05: 30$ \\
\hline SER_12 & May 30, 2010 & $13: 20$ & August 27, 2011 & $04: 30$ \\
\hline
\end{tabular}

and Walz, 1998; Ietswaart et al., 1999; Scherwass et al., 2010; Hardenbicker et al., 2015).

One of the most important issues in designing a Lagrangian survey is the accurate measurement of river water velocity and, subsequently, the estimation of the timing of sample collection. This task can be particularly complicated in hydrologically complex and highly variable systems. Drifting devices (freely floating or manned), although widely employed for tracking the movement of oceanic water masses, have rarely been used in river ecology and, more specifically, in Lagrangian surveys (see Gruberts et al., 2012 and references therein). Tracers have also been employed to determine transport times (e.g. Guhr et al., 2003). More often, hydrodynamic model simulations of water transport time are used, for example the QSIM and HYDRAX models for the Elbe river (Zimmermann-Timm et al., 2007; Hardenbicker et al., 2015) and the Rhine Alarm Model (de Ruyter van Steveninck et al., 1992; Ietswaart et al., 1999; Scherwass et al., 2010). These models are fed by real-time in-situ hydrological and meteorological data, and predict river flow at various temporal resolutions to which different probability values can be associated.

The primary aim of this work is to investigate the large-scale variability in water quality and zooplankton community abundance and composition during downstream transport in a large, lowland river (Po river, Italy) by means of Lagrangian samplings under different hydrological and seasonal conditions. It is the first time that such an approach is applied to this river.

We hypothesized that water quality and zooplankton abundance/composition should display little or no downstream variability during relatively high spring discharge rates and corresponding low water residence time. On the contrary, under summer low discharge levels, a downstream gradient in hydrochemical and biological variables is expected, because of the longer water residence time enhancing the role of local biogeochemical and ecological processes. More specifically, we expect a longitudinal shift in community structure from an assemblage dominated by littoral/epibenthic taxa to a progressively larger contribution of truly planktonic taxa during downstream transport. The influence of the major tributaries on the spatial variability observed in the Po river is also assumed to be more important in spring, when conditions in the Po are less favourable for the development of an abundant autochthonous community.

This paper largely expands upon a preliminary account of some of the results which have appeared as an extended abstract (Bertani et al., 2014).

\section{MATERIALS AND METHODS}

\section{Study area}

The Po is the main Italian river, both in terms of length $(652 \mathrm{~km})$ and catchment surface $\left(70700 \mathrm{~km}^{2}\right)$. The natural meandering course of the river has been radically modified and partially straightened over the centuries, so that the middle and lower reaches are now completely confined within artificial banks, resulting in low hydrological connectivity between the main river channel and floodplain backwaters. At the closing station of Pontelagoscuro, located just upstream of the river delta, the mean annual discharge (period 1918-2003) is $1525 \mathrm{~m}^{3} \mathrm{~s}^{-1}$ (Syvitski and Kettner, 2007). The annual hydrological regime is strongly influenced by the seasonal pattern of precipitation, land use and water abstractions, with low water levels (down to $200 \mathrm{~m}^{3} \mathrm{~s}^{-1}$ ) usually occurring during summer, and floods (up to over $10000 \mathrm{~m}^{3} \mathrm{~s}^{-1}$ ) in late fall and spring (Zanchettin et al., 
2008). Four left tributaries (Ticino, Adda, Oglio and Mincio) make up about $50 \%$ of the total water discharge of the Po, with average discharges of 350, 190, 140 and $60 \mathrm{~m}^{3} \mathrm{~s}^{-1}$, respectively.

Seventeen million people inhabit the river catchment area, which sustains the largest proportion of the national agricultural and industrial production. High nutrient loads arising from urbanization and agricultural activities support high levels of primary production in the lowland river section, especially during summer, when chlorophyll- $a$ concentrations typically reach values up to $75 \mu \mathrm{g} \mathrm{L}^{-1}$ (Rossetti et al., 2009; Viaroli et al., 2013a).

\section{Modeling of water transport time}

Water transport time along the river was simulated through the operational forecasting system Po-Flood Early Warning System (Po-FEWS) of the Emilia-Romagna Environmental Protection Agency (ARPA Emilia-Romagna) (Vezzoli et al., 2013). This system was developed and is routinely operated by ARPA Emilia-Romagna to predict flood events in the Po river basin (Ricciardi et al., 2013). It is based on real-time hydro-meteorological data collected by a monitoring network spread over the whole river basin (588 water level gauges and 1014 rain gauges) and on forecasted meteorological conditions provided by a non-hydrostatic model with lead time of 3 and 15 days. These data feed a coupled rainfall/runoff and hydrodynamic model that generates forecasting scenarios of river discharge and water travel time. Simulations of water velocity along the river under projected meteorological conditions were run two days before each field survey, and results were used to determine the time of sampling at each station. Model performance was assessed by comparing simulated and observed discharge values at six gauging stations along the considered river stretch.

\section{Field sampling and laboratory analyses}

Two surveys were carried out: one in the period 26-30 May, 2010 (spring survey), and one in the period 19-27 August, 2011 (summer survey). In both cases, 12 stations along a 332-km stretch of the Po river lowland reach were sampled (Table I; Figure 1). The most upstream station (Rea) is located $269 \mathrm{~km}$ downstream of the headwaters. The four major tributaries (Ticino, Adda, Oglio and Mincio) along the considered river stretch were also sampled at their mouths. For abbreviations of sampling and gauging stations used hereafter in the text and figures, see caption of Figure 1.

Zooplankton and surface water samples were taken from floating pontoons that allowed us to reach the main current in the river channel. Water temperature and electric conductivity (EC) were measured with a multiparametric probe (YSI Model 85). pH was determined with a pH-meter (Radiometer TIM 90), using a GK $2401 \mathrm{C}$ combined electrode

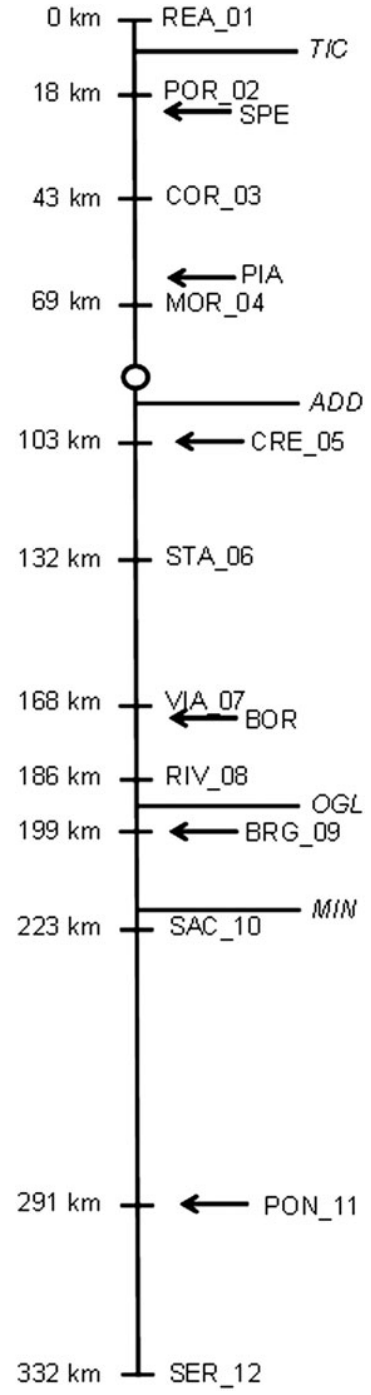

Figure 1. Schematic diagram of the middle reach of the Po river and its main tributaries (in italics) showing the sampling sites. Cumulative distances between sampling sites are also given. The Isola Serafini dam is shown by an open circle. Gauging stations are indicated by arrows. REA_01: Rea; TIC: Ticino river; POR_02: Portalbera; SPE: Spessa; COR_03: Corte Sant'Andrea; PIA: Piacenza; MOR_04: Mortizza; ADD: Adda river; CRE_05: Cremona; STA_06: Stagno; VIA_07: Viadana; BOR: Boretto; RIV_08: Riva di Suzzara; OGL: Oglio river; BRG_09: Borgoforte; MIN: Mincio river; SAC_10: Sacchetta; PON_11: Pontelagoscuro; SER_12: Serravalle

(Radiometer). Dissolved oxygen (DO) was measured with the Winkler method (American Public Health Association et al., 1998). Total alkalinity (TA) was determined by potentiometric end-point titration and linearization according to Rodier (1978). Chlorophyll- $a$ (Chl- $a$ ) concentration was determined spectrophotometrically after acetone extraction (Golterman et al., 1978). Suspended particulate matter (SPM) was determined after drying filters at $70^{\circ} \mathrm{C}$ (American Public Health 
Association et al., 1998). Standard spectrophotometric analyses were applied for soluble reactive phosphorus (SRP) (Valderrama, 1977), dissolved reactive silica (DRSi) (Golterman et al., 1978) and nitric $\left(\mathrm{NO}_{3}-\mathrm{N}\right)$, nitrous $\left(\mathrm{NO}_{2}-\mathrm{N}\right)$, and ammonium nitrogen $\left(\mathrm{NH}_{4}-\mathrm{N}\right)$ (American Public Health Association et al., 1998). Dissolved inorganic nitrogen (DIN) was determined as the sum of ammonia, nitrite and nitrate.

Zooplankton samples were taken by lowering a $15-\mathrm{L}$ bucket into the river; water was then filtered through a $50-\mu \mathrm{m}$ net until reaching a volume of $60 \mathrm{~L}$. Samples were immediately preserved in a $4 \%$ buffered formalin solution. Rotifers and microcrustaceans were identified to the lowest possible taxonomic level, except for bdelloid rotifers, harpacticoids and copepod juvenile stages, these latter assigned either to nauplii or copepodites, separately for calanoids and cyclopoids. The following references were used for taxa identification: Gurney (1933), Kiefer (1968), Dussart (1969), Dussart and Defaye (1995), Einsle (1996), Karaytug (1999) and Ueda and Reid (2003) for copepods, Margaritora (1985) and Alonso (1996) for cladocerans, Ruttner-Kolisko (1974), Koste (1978), Braioni and Gelmini (1983), Segers (1994, 1995a, 1995b), Segers et al. (1994), Nogrady et al. (1995), De Smet (1996), De Smet and Pourriot (1997) and De Smet and Gibson (2008) for monogonont rotifers. Diploid subitaneous and resting eggs of the dominant large brachionid rotifers (Brachionus calyciflorus and B. quadridentatus) were counted collectively, because the two species produce eggs of very similar shape and size. Eggs of other rotifer taxa were not enumerated as they were too small to be quantitatively retained by the plankton net. Metazoans other than rotifers, cladocerans and copepods were also enumerated and grouped into broad taxonomic categories.

\section{Data analysis}

The Wilcoxon signed-rank test for paired samples was used to compare values of physico-chemical variables and Chl- $a$ across years and between tributaries and corresponding downstream stations in the Po river (Hardenbicker et al., 2015). Spatio-temporal patterns in zooplankton community structure were explored by means of non-metric multidimensional scaling (NMDS) performed on a Bray-Curtis distance matrix (Legendre and Legendre, 1998). Extremely rare taxa (rotifer and crustacean species that do not reach in at least one sampling date 1000 ind $\mathrm{m}^{-3}$ and 500 ind $\mathrm{m}^{-3}$, respectively) were excluded from the analysis. Environmental variables with significant $(p<0.05)$ correlations to either ordination axis are shown on the NMDS biplot. Non-parametric permutational multivariate analysis of variance (PERMANOVA; Anderson, 2001) with 999 permutations was performed to test for significant differences in zooplankton community structure across years and between tributaries and corresponding downstream stations in the Po river. Analyses were performed with the software R ( $\mathrm{R}$ Core Team, 2015) using the package vegan (version 2.3-0; Oksanen et al., 2015) for NMDS and PERMANOVA. Correlations between environmental variables and NMDS ordination axes were explored using the envfit function in the vegan package. This function fits vectors of environmental variables onto the NMDS ordination plot, with the vector length being proportional to the correlation between the variable and the ordination (Oksanen et al., 2015).

The Shannon diversity index $(\mathrm{H})$ was calculated using the package PAST version 1.06 (Hammer et al., 2001).

\section{RESULTS}

\section{Hydrology and hydrodynamic model performance}

In early May 2010 a flood occurred, after which river flow steadily decreased until the beginning of sampling. During the spring survey, discharge remained relatively stable, showing only a slight increasing trend (from 1275 to $1451 \mathrm{~m}^{3} \mathrm{~s}^{-1}$ at PIA, from 1762 to $2038 \mathrm{~m}^{3} \mathrm{~s}^{-1}$ at BRG_09, and from 1874 to $2175 \mathrm{~m}^{3} \mathrm{~s}^{-1}$ at PON_11) (Figure 2). The percentage error between simulated and observed discharge values ranged between $-5.52 \%$ and $0.42 \%\left(R^{2}=0.99\right)$. According to the model, water velocity ranged between 0.72 and $1.15 \mathrm{~m} \mathrm{~s}^{-1}$ in different river sections, with an average value of $0.92 \mathrm{~m} \mathrm{~s}^{-1}$ along the investigated stretch.

An increase in river discharge was recorded in the first half of August 2011, followed by a gradual decrease in the subsequent days. On 19 August, values of 414,510 and $646 \mathrm{~m}^{3} \mathrm{~s}^{-1}$ were observed at the gauging stations of PIA, BRG_09 and PON_11, respectively. Discharge remained then relatively constant for most of the study period (Figure 2). The percentage error between simulated and observed flow values ranged between $-6.00 \%$ and $22.84 \%\left(R^{2}=0.76\right)$. Estimated current velocity varied between 0.40 and $0.74 \mathrm{~m} \mathrm{~s}^{-1}$ in different river segments, with a mean of $0.57 \mathrm{~m} \mathrm{~s}^{-1}$.

\section{Hydrochemistry}

In May 2010, EC had no clear longitudinal trend, although the highest values were recorded downstream of the junction with the OGL river, which showed a maximum of $504 \mu \mathrm{S} \mathrm{cm}^{-1}$. DO saturation ranged between 82 and $111 \%$ at all sites. SPM exhibited a downstream decreasing trend down to a minimum of $45.5 \mathrm{mg} \mathrm{L}^{-1}$ at BRG_09, followed by an increase in the lowermost stations. Among the tributaries, OGL was the only one showing SPM levels higher than those recorded in the Po $\left(65.7 \mathrm{mg} \mathrm{L}^{-1}\right)$ (Figure 3).

Nitrate was by far the dominant form of inorganic nitrogen. DIN concentrations in the Po varied between $1401 \mu \mathrm{g} \mathrm{L}^{-1}$ at STA_06 and $2187 \mu \mathrm{g} \mathrm{L}^{-1}$ at BRG_09, with the highest values recorded immediately downstream of 

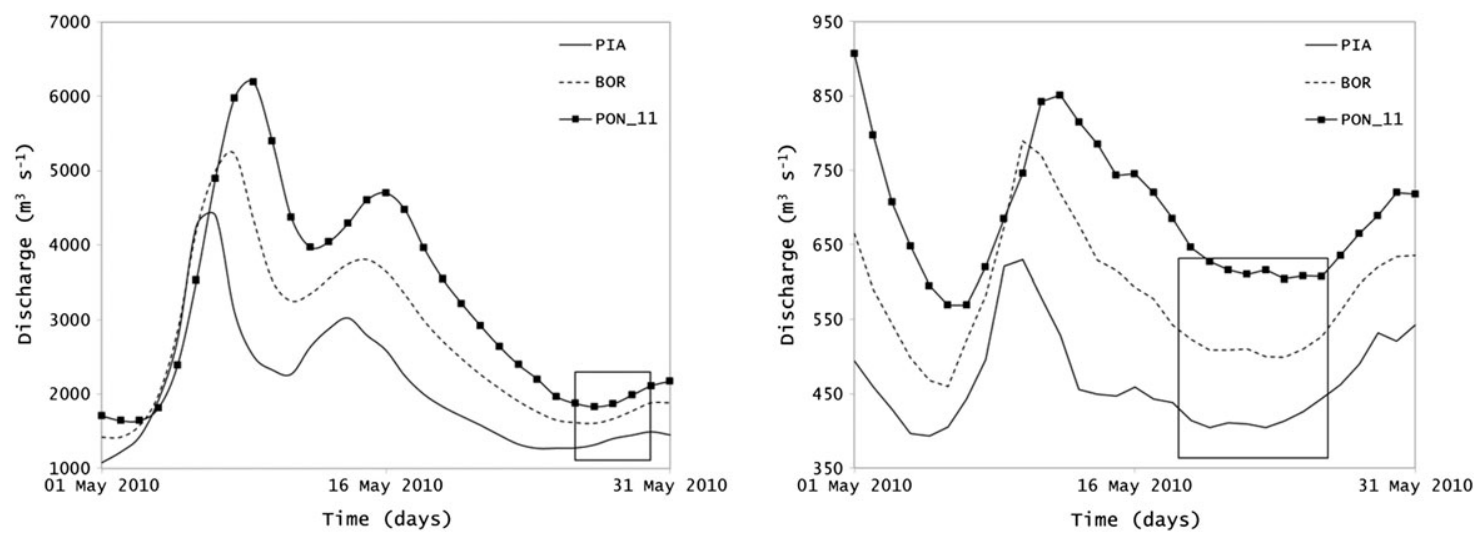

Figure 2. Discharge values $\left(\mathrm{m}^{3} \mathrm{~s}^{-1}\right)$ of the Po River in May 2010 (left) and August 2011 (right). Data from only three gauging stations (PIA: Piacenza; BOR: Boretto; PON_11: Pontelagoscuro) are reported for clarity. Sampling periods are indicated by rectangles

the OGL confluence. Concentrations in the tributaries were comparable to those recorded in the Po, with the exception of OGL, where a DIN content of $4422 \mu \mathrm{g} \mathrm{L}^{-1}$ was detected. SRP concentrations were between 29 (COR_03) and $12 \mu \mathrm{gL}^{-1}$ (RIV_08) along the Po, while the lowest SRP concentration was recorded at MIN $\left(8 \mu \mathrm{gL}^{-1}\right)$. The DIN: SRP molar ratio was highly variable in the Po (ranging from 136 at COR_03 to 348 at BGR_09) and even more so in the tributaries (from 185 at TIC to 507 at OGL). DRSi reached the highest values at the two most upstream Po stations $\left(\sim 2.5 \mathrm{mg} \mathrm{L}^{-1}\right)$; at the other stations concentrations ranged between $1.89 \mathrm{mg} \mathrm{L}^{-1} \quad$ (CRE_05) and $2.25 \mathrm{mg} \mathrm{L}^{-1}$ (MOR_04), while the tributaries exhibited lower values. The molar ratios of DRSi to DIN were largely $<1$ at all sites. The Chl- $a$ content in the Po varied between $2.4 \mu \mathrm{g} \mathrm{L}{ }^{-1}$ (STA_06) and $6.7 \mu \mathrm{gL}^{-1}$ (SER_12), with the most downstream stations generally showing the highest values. Among the tributaries, particularly high Chl- $a$ levels occurred at MIN (20.9 $\left.\mu \mathrm{g} \mathrm{L}^{-1}\right)$ (Figure 3).

In August 2011, EC decreased along the first four Po stations, followed by a gradual increase along the remaining sites. The lowest tributary EC was measured at TIC $\left(278 \mu \mathrm{S} \mathrm{cm}^{-1}\right)$, while at OGL a value of $600 \mu \mathrm{S} \mathrm{cm}^{-1}$ was observed. DO saturation ranged between 89 and $153 \%$ in the Po, with no clear longitudinal trend; the tributaries showed progressively increasing oxygen contents from the uppermost one (77\% at TIC) to the most downstream one $\left(125 \%\right.$ at MIN). SPM varied between $18.6 \mathrm{mg} \mathrm{L}^{-1}$ (MOR_04) and $41.5 \mathrm{mgL}^{-1}$ (BRG_09), with the most downstream stations exhibiting the highest values. The lowest SPM levels were recorded at TIC and ADD (6.3 and $10.4 \mathrm{~m} \mathrm{~L}^{-1}$, respectively), while OGL showed the highest value $\left(52.1 \mathrm{mg} \mathrm{L}^{-1}\right)$ (Figure 3 ).

Also in the summer survey DIN was composed for the most part by nitrate, which varied between $1201 \mu \mathrm{gL}^{-1}$ (MOR_04) and $2125 \mu \mathrm{gL}^{-1}$ (VIA_07) in the Po.
Particularly high nitrate levels were found at OGL $\left(4840 \mu \mathrm{g} \mathrm{L}^{-1}\right) . \mathrm{N}^{-N}{ }_{2}$ and $\mathrm{N}-\mathrm{NH}_{4}$ were $\leq 100 \mu \mathrm{g} \mathrm{L}{ }^{-1}$ at all sites. SRP concentrations remained $<20 \mu \mathrm{g} \mathrm{L}^{-1}$ at most of the middle and lower stations, with the exception of SER_12 that showed a peak of $28 \mu \mathrm{gL}^{-1}$. The DIN:SRP ratio varied from 94 (COR_03) to 1262 (POR_02) in the Po, and from 166 (MIN) to 264 (OGL) in the tributaries. DRSi had a clear downstream decreasing trend in the Po, from $3.49 \mathrm{mg} \mathrm{L}^{-1}$ at REA_01 to $1.27 \mathrm{mg} \mathrm{L}^{-1}$ at SER_12; in the tributaries, the highest value was found at OGL $\left(2.13 \mathrm{mg} \mathrm{L}^{-1}\right)$ and the lowest at MIN $\left(0.83 \mathrm{mg} \mathrm{L}^{-1}\right)$. The DRSi:DIN ratio in the Po was $>1$ only at REA_01, and the lowest values were found at PON_11 and SER_12 ( $\sim 0.37)$; in the tributaries, the ratio ranged between 0.28 (OGL) and 0.72 (TIC). While no clear trend was evident for Chl- $a$ concentrations, the highest values $\left(\sim 30 \mu \mathrm{g} \mathrm{L}^{-1}\right)$ were found at the most downstream stations, except for SER_12 $\left(14.1 \mu \mathrm{g} \mathrm{L}^{-1}\right)$. With the only exception of MIN $\left(22.2 \mu \mathrm{g} \mathrm{L}^{-1}\right)$, the tributaries had relatively low Chl- $a$ concentrations $\left(\leq 2.6 \mu \mathrm{gL}^{-1}\right)$ (Figure 3).

Most of the hydrochemical variables showed significant differences across years (Wilcoxon signed-rank test; Temperature: $Z=0, p<0.01$; EC: $Z=1, p<0.01$; TA: $Z=1$, $p<0.01$; DO saturation: $Z=4.5, p<0.01$; SPM: $Z=130$, $p<0.01$; Chl- $a: Z=7, p<0.01$ ), with the exception of $\mathrm{pH}(Z=41, p=0.18), \operatorname{SRP}(Z=83, p=0.45), \mathrm{DIN}(Z=73$, $p=0.82)$ and DRSi $(Z=56, p=0.55)$. Differences between values of hydrochemical variables measured in the tributaries vs. corresponding downstream Po river stations were not statistically significant (Wilcoxon signed-rank test, $p>0.05$ in all cases), though this was most likely because of the small sample size $(n=8)$ and the fact that differences between tributaries and Po river had opposite signs, with some tributaries having consistently lower values and some others having higher values than those found in the Po. 

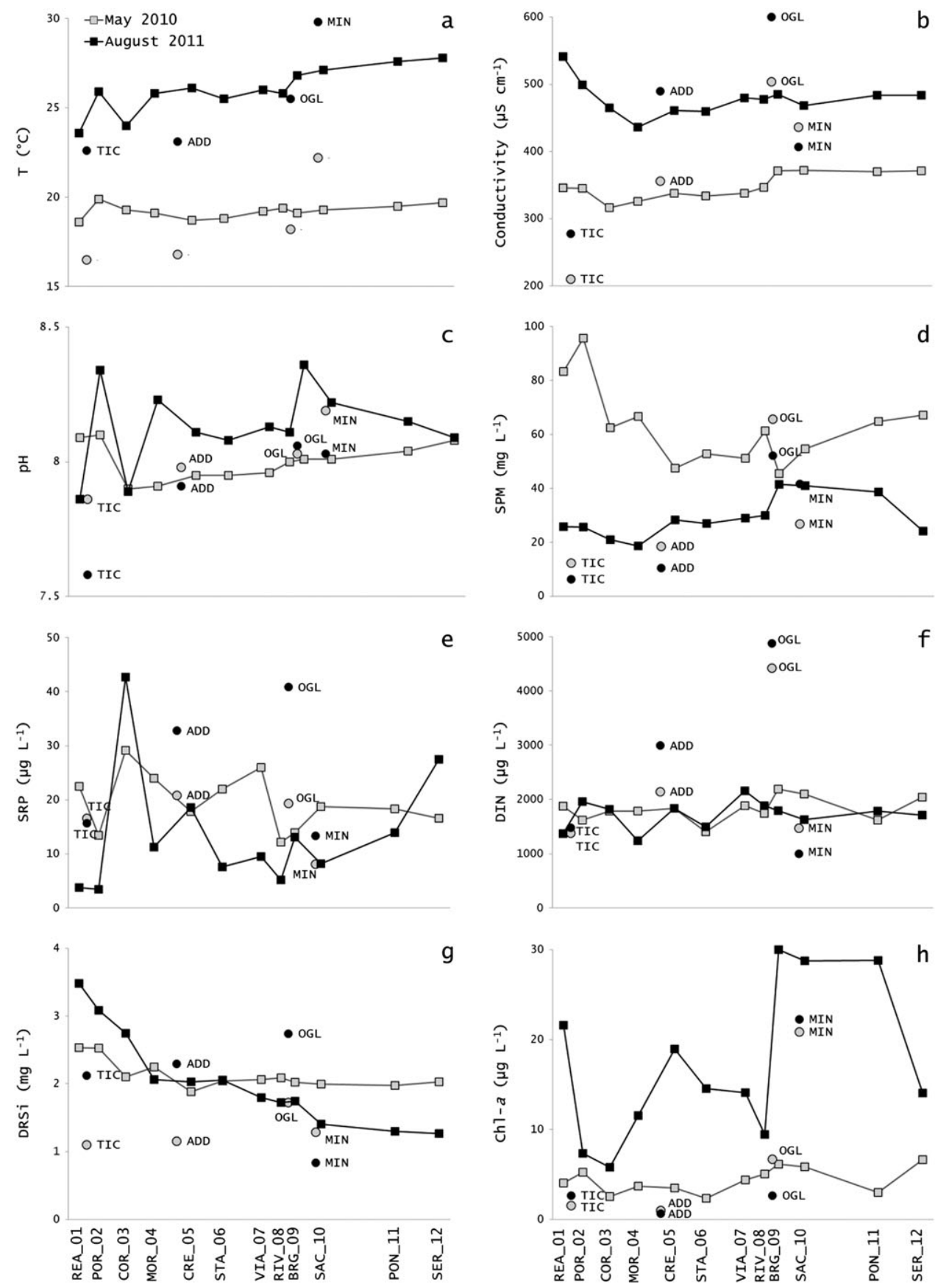

Figure 3. Variation in a) water temperature, b) conductivity, c) $\mathrm{pH}$, d) suspended particulate matter (SPM), e) soluble reactive phosphorus (SRP), f) dissolved inorganic nitrogen (DIN), g) dissolved reactive silica (DRSi) and h) chlorophyll- $a$ (Chl- $a$ ) during the Lagrangian surveys carried out in May 2010 (grey symbols) and August 2011 (black symbols). Square symbols indicate the Po river sampling stations, circles indicate the tributaries

\section{Zooplankton assemblage}

In the spring survey, a total of 117 taxa were identified: 99 rotifers, 13 cladocerans and 5 copepods. Total zooplankton density fluctuated around 30 ind $\mathrm{L}^{-1}$ along the first eight stations in the Po, it sharply peaked downstream of the
MIN inflow (165 ind $\mathrm{L}^{-1}$ ) and decreased to values around 100 ind $\mathrm{L}^{-1}$ at the two most downstream sites. Zooplankton densities in the first two tributaries were comparable to those recorded in the uppermost segment of the Po. At OGL total zooplankton abundance reached 65 ind $\mathrm{L}^{-1}$, while at MIN a peak of 747 ind $\mathrm{L}^{-1}$ was detected (Figure 4). 

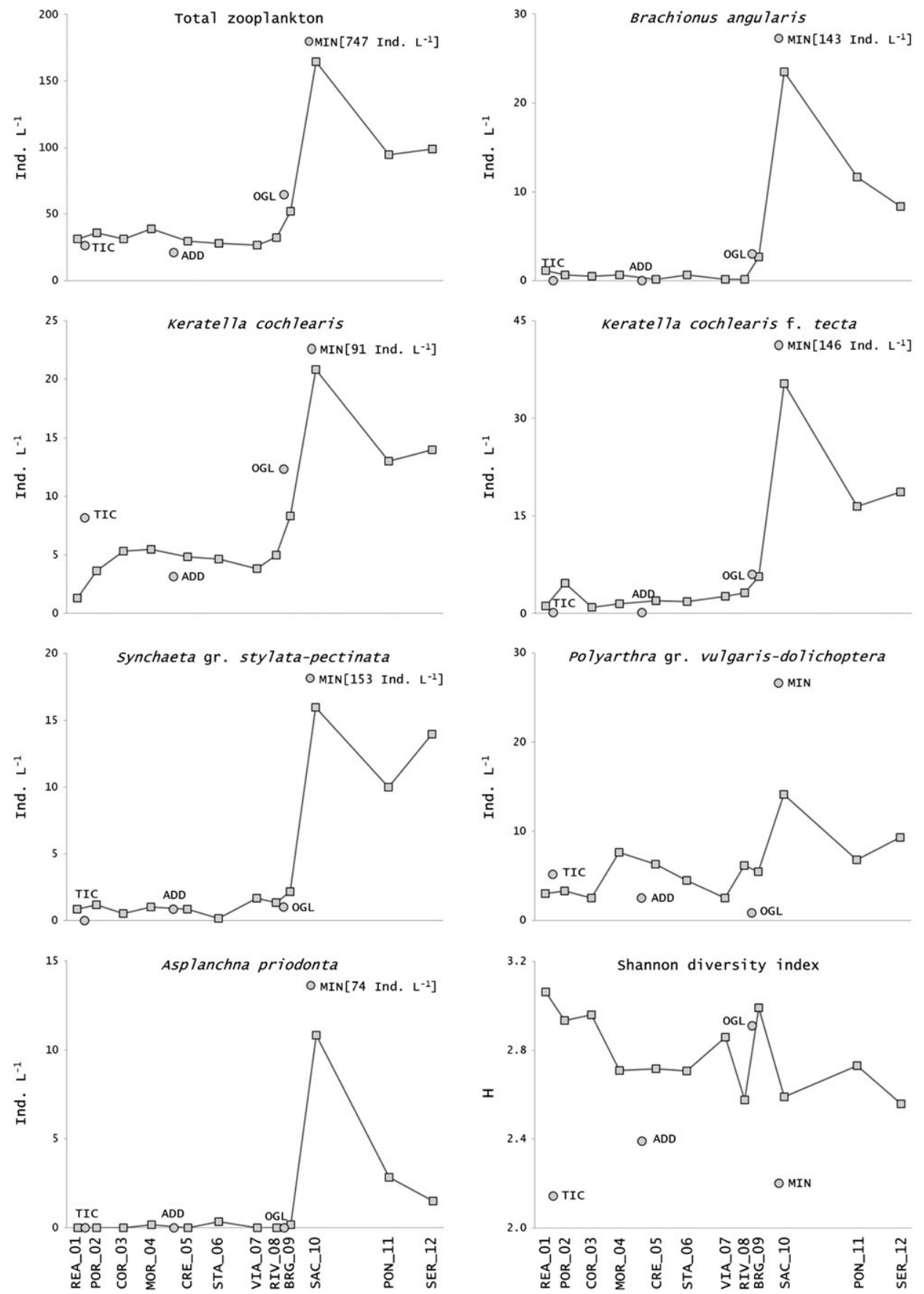

Figure 4. May 2010: density of total zooplankton, selected rotifer taxa and Shannon diversity index calculated for the zooplankton assemblage. Square symbols indicate the Po river sampling stations, circles indicate the tributaries. Densities exceeding the maximum y-axis value are between square brackets

The NMDS ordination plot showed no clear spatial pattern in Po river community structure upstream of MIN in spring 2010, with the Po river stations grouped into a cluster with no apparent longitudinal structure (Figure 8). The MIN tributary segregated from the rest of the samples primarily along the first NMDS axis, in the direction of increasing Chl- $a, \mathrm{pH}$ and DO saturation. The three Po stations downstream of the MIN tributary were somewhat separated from the cluster of upstream Po stations and shifted toward the MIN sample. Overall, no significant differences between 

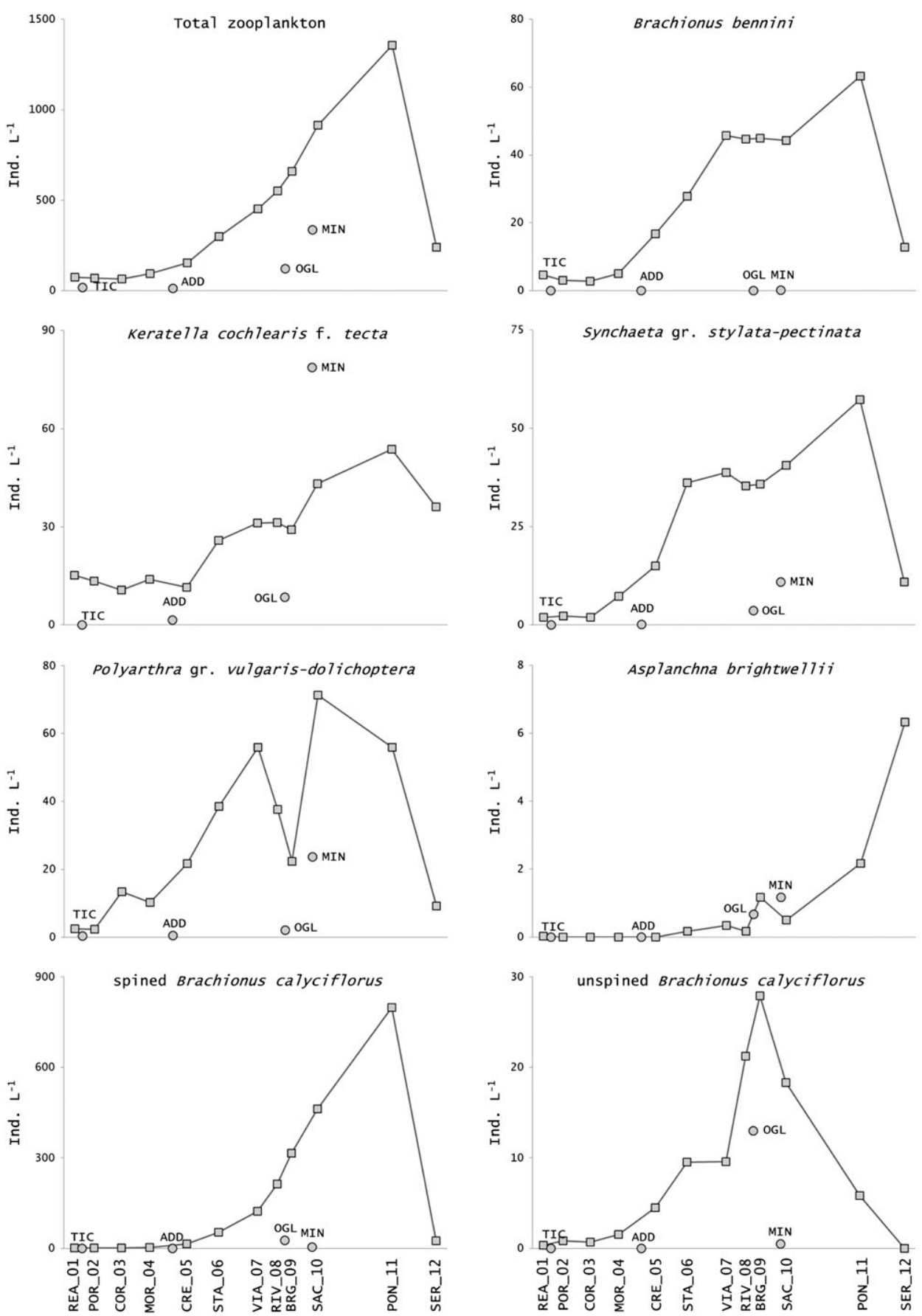

Figure 5. August 2011: density of total zooplankton and selected rotifer taxa calculated for the zooplankton assemblage. Square symbols indicate the Po river sampling stations; circles indicate the tributaries

community structure in the tributaries vs. corresponding downstream Po river sites were found (PERMANOVA; $F=0.69, p=0.64$ ).

Zooplankton density was mainly sustained by rotifers, which made up over $90 \%$ of the community at all sites. Loricate taxa constituted 29 to $43 \%$ of the rotifer assemblage in the first eight Po stations and at TIC and ADD, while in the two most downstream tributaries and in the last four Po sites their share increased to $\sim 60 \%$ (Figure 7). The ratio of truly planktonic to littoral/epibenthic rotifer taxa showed a gradual downstream increase, from a minimum of $46 \%$ at REA_01 to a maximum of 90\% at SER12 (Figure 7). While 
at ADD littoral/epibenthic species tended to dominate, with a share of $56 \%$, in the other tributaries planktonic taxa made up 63 to $98 \%$ of the whole assemblage (Figure 7). The percentage composition of the rotifer assemblage in terms of the most abundant taxa remained quite similar in the first nine stations along the Po. Specifically, bdelloids, Keratella
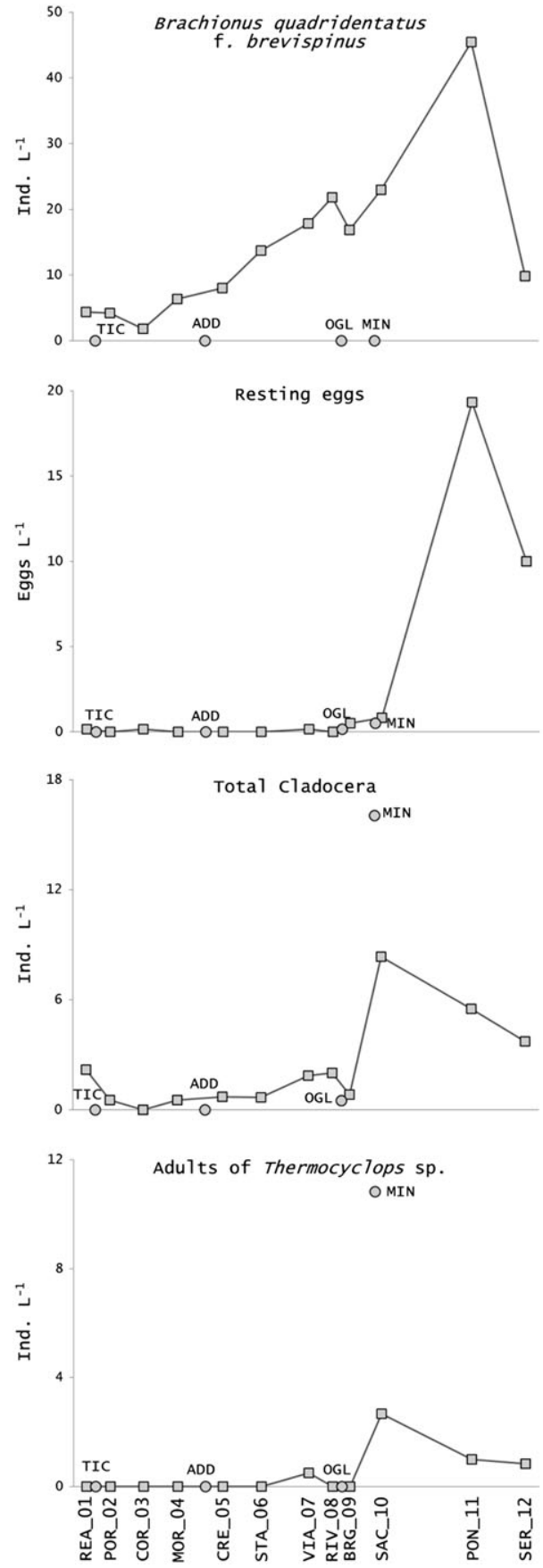

cochlearis, K. cochlearis f. tecta, Synchaeta gr. tremulaoblonga and Polyarthra gr. vulgaris-dolichoptera made up a large proportion of the community in the Po sites as well as in the first three tributaries (Figure 4). At MIN and at the Po stations downstream of its confluence, the share of bdelloids and Polyarthra decreased in favour of that of $K$.
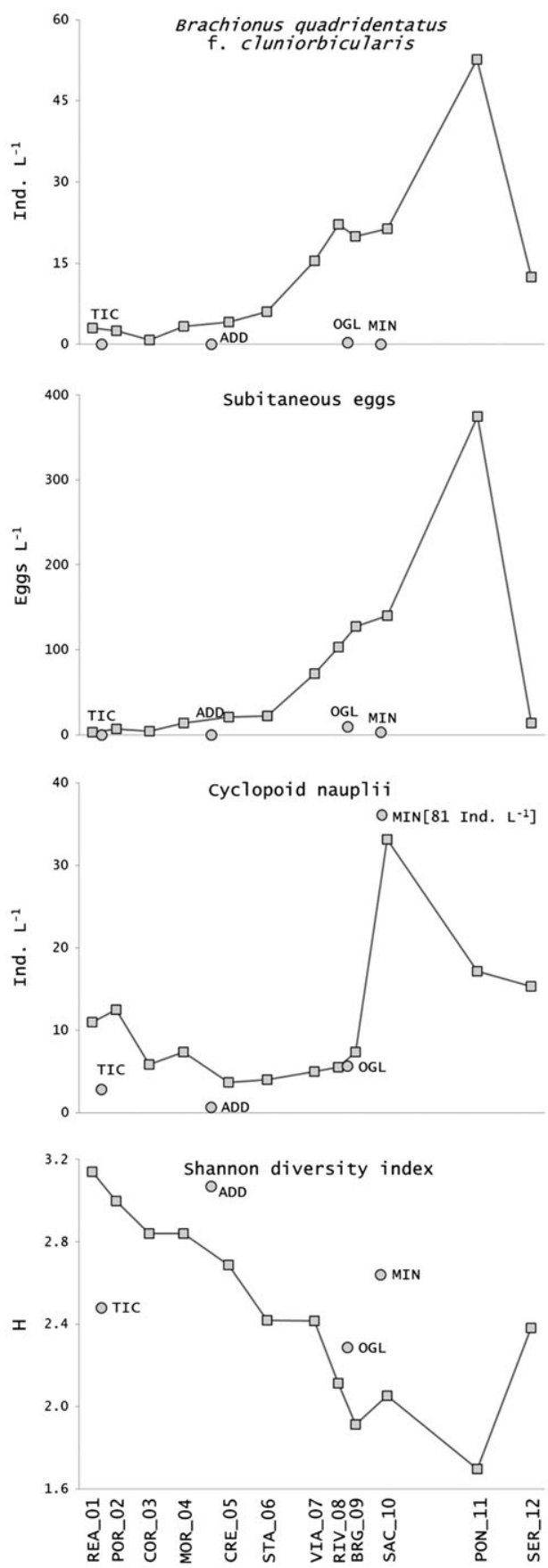

Figure 6. August 2011: density of B. quadridentatus f. brevispinus, B. quadridentatus f. cluniorbicularis, resting and subitaneous eggs of $B$. calyciflorus and B. quadridentatus (aggregated data), total Cladocera, cyclopoid nauplii, adults of Thermocyclops sp. and Shannon diversity index. Square symbols indicate the Po river sampling stations; circles indicate the tributaries. Densities exceeding the maximum y-axis value are between square brackets 
cochlearis f. tecta, Asplanchna priodonta, Brachionus angularis and Synchaeta gr. stylata-pectinata. These latter species showed low abundances along most of the river stretch and then sharply peaked at MIN and in the following Po stations (Figure 4). On the contrary, some littoral/epibenthic taxa showed a clear decreasing pattern in the downstream direction, e.g. Lecane luna, Lepadella patella, Trichocerca porcellus and bdelloid rotifers.

Cladocerans never exceeded 1 ind $\mathrm{L}^{-1}$ in the Po and in the two uppermost tributaries, while slightly higher densities were recorded at OGL and MIN (Figure 4). The rest of the zooplankton community consisted mainly of copepod larval stages (Figure 4), with abundances $<4$ ind $\mathrm{L}^{-1}$ at all stations except from MIN, where copepods reached 13 ind $\mathrm{L}^{-1}$.

The Shannon diversity index ranged between 2.56 (SER_12) and 3.06 (REA_01), and it declined in the downstream direction, with the exception of a relatively high value recorded right after the inflow of the OGL river, which had the highest diversity among the tributaries (Figure 4).

Among other invertebrates, nematodes were the only group found in all samples, with maxima of $\sim 3$ ind $\mathrm{L}^{-1}$ in the first three Po stations and at OGL. Bivalve veligers occurred in the Po downstream of CRE_05 and at MIN. Dipteran larvae and tardigrades were present in most of the sampled sites, but always with abundances $<1$ ind $\mathrm{L}^{-1}$. Ostracods were rarely found in the Po and with negligible abundances.

In the summer survey, a total of 132 zooplankton taxa were identified: 107 rotifers, 15 cladocerans and 10 copepods. Total zooplankton density showed a gradual increasing downstream trend, with a maximum of 1358 ind $\mathrm{L}^{-1}$ at PON_11, followed by a sharp decrease at SER_12 (241 ind $\mathrm{L}^{-1}$ ). Among the tributaries, the highest abundances were found at OGL (121 ind $\left.\mathrm{L}^{-1}\right)$ and MIN (337 ind $\left.\mathrm{L}^{-1}\right)$ (Figure 5).

Contrary to the spring survey, in summer 2011 the Po river stations showed a strong longitudinal gradient in community structure, with progressively downstream sites ordered along the first NMDS axis in the direction of increasing Chl- $a$, DO and pH (Figure 8). The three most upstream tributaries tended to separate along the second NMDS axis, corresponding to increasing conductivity, temperature
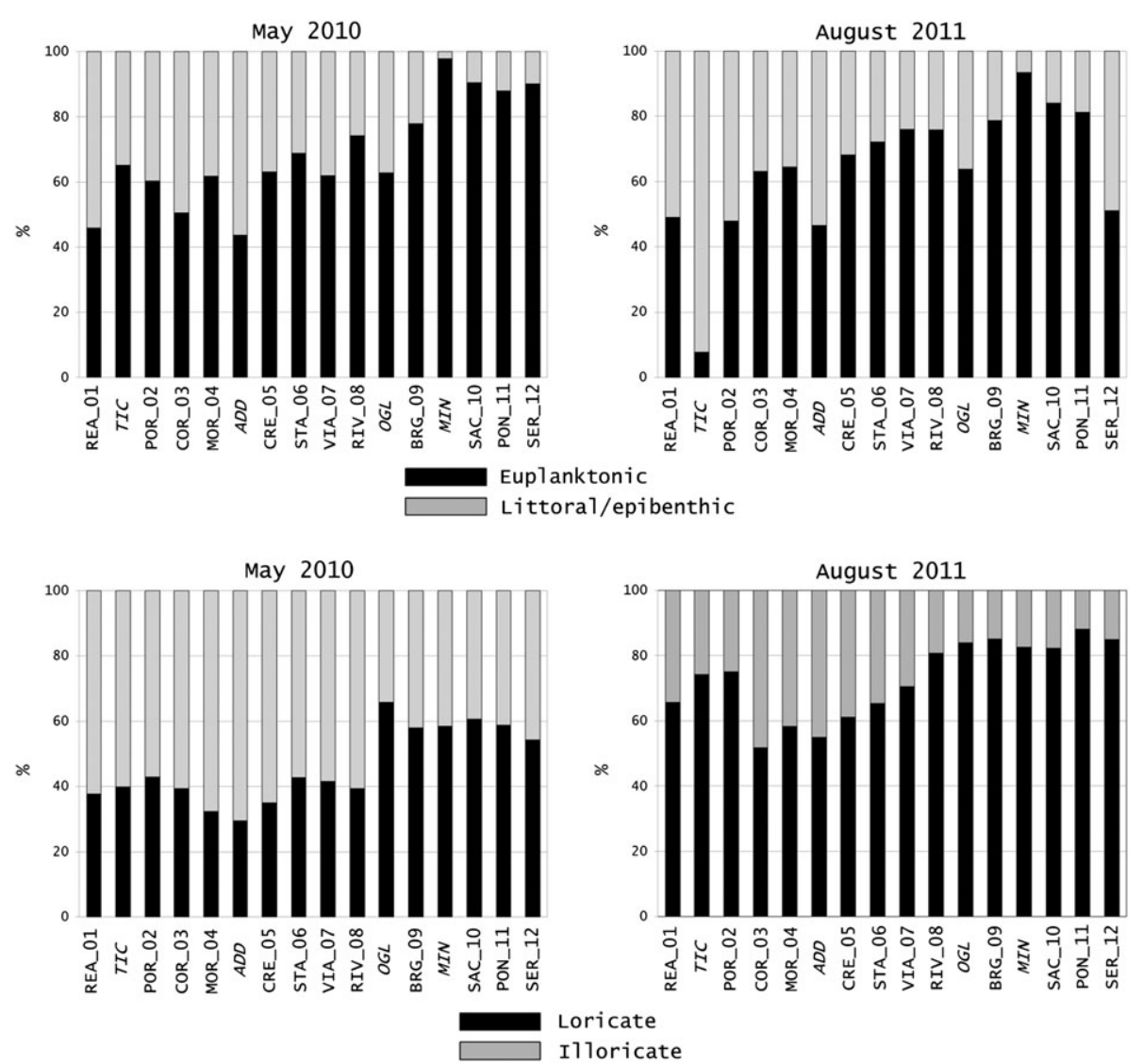

Figure 7. Percentage of euplanktonic (black bars) vs. littoral/epibenthic (grey bars) rotifer taxa (upper panels) and percentage of loricate (black bars) vs. illoricate (grey bars) rotifer taxa (lower panels) recorded at stations along the Po River and in the tributaries (in italics) in May 2010 and August 2011 
and DRSi, while the summer MIN sample formed a separate cluster with the spring MIN sample. Substantial differences in community structure across years were confirmed by the PERMANOVA analysis $(F=11.0, p<0.01)$, while no significant differences between community structure in the tributaries vs. downstream Po river sites were detected (PERMANOVA; $F=1.56, p=0.23$ ).

As in the spring survey, rotifers were the numerically dominant group. Specifically, brachionid rotifers were by far the most abundant taxonomic group (Figures 5 and 6). Spined $B$. calyciflorus largely contributed to the zooplankton peak at PON_11, with a density of 798 ind $\mathrm{L}^{-1}$. At this site, a peak in diploid subitaneous and resting eggs of $B$. calyciflorus and $B$. quadridentatus was also recorded (Figure 6). Unspined $B$. calyciflorus never exceeded 30 ind $\mathrm{L}^{-1}$, and it sharply declined in coincidence with the peak in the spined morph. Most brachionid species had remarkably lower abundances in the tributaries than in the Po; on the contrary, at MIN B. angularis, B. forficula, K. cochlearis and K. cochlearis f. tecta (Figure 5) reached higher densities than in the Po. Rotifers belonging to the family Synchaetidae, namely Polyarthra gr. vulgaris dolichoptera, Synchaeta gr. stylata-pectinata (Figure 5) and S. gr. tremula-oblonga also displayed relatively high abundances in the Po, with comparatively low densities in the tributaries. The predator Asplanchna brightwellii showed an exponential increase at the lowermost stations (Figure 5).

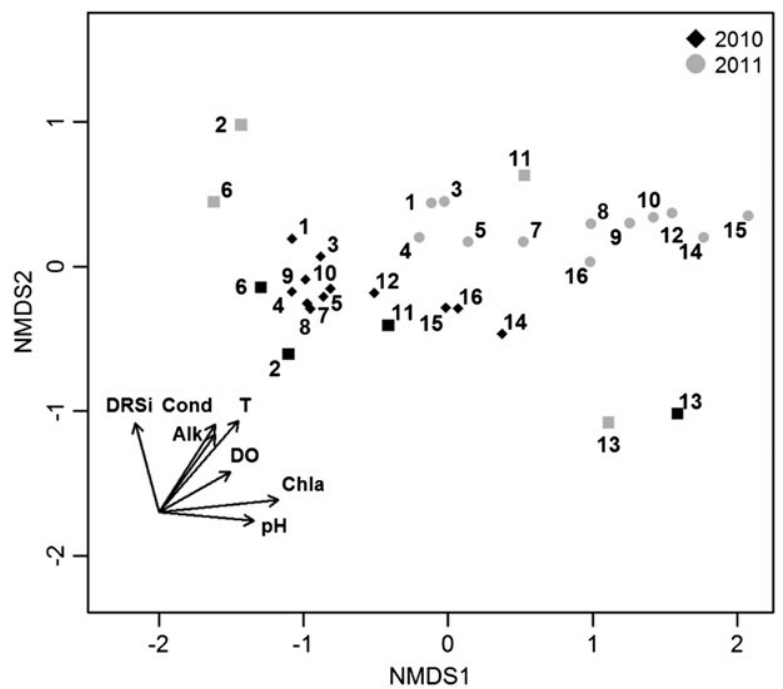

Figure 8. NMDS ordination biplot of zooplankton communities sampled along the Po river and in four major tributaries in spring 2010 (black) and summer 2011 (grey). Tributaries are indicated by square symbols, and numbers indicate progressively downstream stations and tributaries as follows: 1: REA_01; 2: TIC; 3: POR_02; 4: COR_03; 5: MOR_04; 6: ADD; 7: CRE_05; 8: STA_06; 9: VIA_07; 10: RIV_08; 11: OGL; 12: BRG_09; 13: MIN; 14: SAC_10; 15: PON_11; 16: SER_12. Environmental variables with significant $(p<0.05)$ correlations to either axis are shown in the bottom left corner. Stress: 0.05
Euplanktonic rotifer taxa were generally more abundant than littoral/epibenthic ones, except for TIC, where planktonic taxa accounted for $<10 \%$. In the Po, a downstream increasing trend in planktonic taxa was observed, followed by a marked drop at the last station. Loricate rotifers were numerically dominant. The highest percentages $(>80 \%)$ were found in the lowermost Po stations and at OGL and MIN (Figure 7).

Microcrustaceans showed relatively low densities in the upper river segment and a sharp increase downstream of the MIN confluence (Figure 6). In particular, peaks of 16 and 81 ind $\mathrm{L}^{-1}$ were recorded at MIN for cladocerans (mainly Moina micrura and Diaphanosoma sp.) and cyclopoid nauplii, respectively. Similarly, cyclopoid adults belonging to Thermocyclops sp. reached a maximum of 11 ind $\mathrm{L}^{-1}$ at MIN, resulting in a density of 3 ind $\mathrm{L}^{-1}$ at the closest downstream Po station (Figure 6).

Dipteran larvae and nematodes were found in most of the sites; their abundances were higher at the uppermost stations of the Po. An opposite trend was observed for bivalve veligers, which showed the highest densities in the middle and lower section of the river, with a peak 6 ind $\mathrm{L}^{-1}$ at SER_12.

In the Po, the Shannon diversity index (Figure 6) showed a clear downstream declining trend paralleled by the increasing dominance of brachionid rotifers; at SER_12, a marked increase was observed, coinciding with the highest density of Asplanchna brightwellii and the decline in most brachionids.

\section{DISCUSSION}

Lagrangian samplings reflect chemical and biological changes of hypothetical water parcels during their downstream transport. The main assumption is that individual water parcels (and therefore dissolved substances and passively advected particles and organisms) travel at the same speed than mean river flow. The presence of retention zones and side arms may slow down portions of the water mass and enhance biogeochemical and biological processes, resulting in an uncoupling between transformation and growth rates and longitudinal transport in the main current (Reckendorfer et al., 1999; Schiemer et al., 2001; Casper and Thorp, 2007). However, in the trait considered in this study, the Po is largely embanked, and river hydrodynamics can be assumed to be only marginally affected by lateral connectivity with the floodplain.

While for the May 2010 survey a very close agreement between observed and simulated discharge values was obtained, in August 2011 actual discharge was somewhat overestimated at the two lowermost stations. This was most likely because of unexpected management activities on the deep sub-alpine lakes during drought periods that can considerably influence flow variability of the main Po river tributaries (Zanchettin et al., 2008). However, 
model performance diminished only in the very final segment of the considered river trait, thereby having only limited impact on the overall survey.

Contrary to what has been observed in spring, a clear downstream increase in water temperature was detected in August, together with an increase in the concentration of SPM, as it is often reported in the potamal trait of large rivers (Zimmermann-Timm et al., 2007; Scherwass et al., 2010). Lower discharge rates and higher residence time in summer resulted in markedly lower SPM and higher EC and TA when compared to spring values (Figure 3). Lower turbulence and turbidity, coupled with higher water temperatures, stimulated phytoplankton growth, as indicated by the notably higher summer Chl- $a$ concentrations, especially in the lower river segment (Figure 3). Accordingly, $\mathrm{pH}$ and DO saturation were also markedly higher in summer, likely as a consequence of the increased photosynthetic activity. These two variables showed similar spatial variability, which was mainly related to the time of sampling, with the highest values generally recorded in the afternoon or early evening, when primary production was at its peak.

The marked longitudinal decrease in DRSi in summer, in coincidence with the downstream increase in Chl- $a$ (Figure 3), can probably be ascribed to uptake by phytoplankton, which is largely dominated by diatoms (Tavernini et al., 2011). Frequent potential Si limitation, especially during summer diatom blooms, has recently been reported in the Po (Viaroli et al., 2013b). On the contrary, the lack of a clear longitudinal pattern for SRP and DIN in both surveys suggests that even during the phytoplankton growing season these nutrients are unlikely to become limiting, because of extremely high loads deriving from agricultural nonpoint sources in the watershed (Viaroli et al., 2013a).

The four tributaries exhibited contrasting hydrochemical and trophic characteristics (Figure 3). We did not observe any detectable impact on the Po water quality, probably because of the relatively low discharge levels of the tributaries when compared to those of the Po itself.

Lagrangian surveys have rarely been applied to the investigation of river zooplankton dynamics. In particular, most of the extant work has been carried out on the River Rhine, where different studies have been performed through the years on a $>600-\mathrm{km}$ river trait, considering both the metazoan and the microbial component of the plankton community, as well as phytoplankton (de Ruyter van Steveninck et al., 1992; Ietswaart et al., 1999; Scherwass et al., 2010). Although a clear downstream increase in some of the hydrochemical variables was observed, such as water temperature, conductivity, turbidity, nitrate, phosphate and silicate, chlorophyll- $a$ concentration as well as rotifer and microcrustacean abundances showed contrasting longitudinal patterns according to the season and the hydrological conditions. While a significant downstream shift in the taxonomic composition of the phytoplankton assemblage was recorded, relatively less information is available on the composition and diversity of the zooplankton component.

A study conducted on a 500-km trait of the River Elbe focused on the taxonomic composition of the phyto- and zooplankton assemblages, which both increased in density during downstream transport (Zimmermann-Timm et al., 2007). No significant longitudinal change in the rotifer community structure was observed, except for a higher relative abundance of brachionids in the lower parts of the river. Further Lagrangian sampling campaigns performed in the period 2009-2011 (Hardenbicker et al., 2015) in the rivers Rhine and Elbe revealed contrasting patterns in longitudinal development of zooplankton abundances, and opposite impacts of tributaries on plankton biomass in the two rivers.

Other Lagrangian drift experiment performed along the rivers Spree (Welker and Walz, 1998) and Daugava (Gruberts et al., 2012; Gruberts and Paidere, 2014) cannot easily be compared to those reported above, as they were carried out in considerably shorter river traits $(21,61$ and $62 \mathrm{~km}$, respectively).

In spring, zooplankton abundance and composition along the Po river did not show significant changes during downstream transport until the confluence of the Mincio river. This confirms our hypothesis that spring flow rates are typically unsuitable for plankton growth in the main channel, as a result of low water residence times, unfavourable physical conditions and low food availability. However, the MIN tributary hosted an exceptionally abundant zooplankton community, and an increase in total zooplankton density was observed in the Po downstream of the MIN inflow (Figure 4). The MIN lower course is highly impounded and regulated, and current is virtually negligible, thus creating favourable conditions for phytoplankton and zooplankton development. As a consequence, despite an average discharge of only $50 \mathrm{~m}^{3} \mathrm{~s}^{-1}$, the influence of this tributary on the Po river zooplankton was still detectable as far as $100 \mathrm{~km}$ downstream of its mouth. Specifically, the community composition recorded downstream of the MIN inflow showed similarities to the assemblage found in the tributary, as indicated by the position of the stations in the NMDS ordination space (Figure 8). To a lesser extent, OGL seemed to affect the Po river community composition too, as shown by the increase in the share of loricate taxa downstream of its mouth (Figure 7). This was mainly because of the higher abundances attained by species of the genus Brachionus at OGL and later at MIN. In particular, in the MIN river a few taxa made up a large proportion of the rotifer assemblage, resulting in a reduced overall diversity. On the contrary, OGL hosted a more diverse and even assemblage, probably because of the higher turbulence and turbidity that may act as disturbance factors, preventing the development of a structured community with few dominant taxa (De Leo and Ferrari, 1993). As a 
consequence, a marked increase in community diversity was observed just downstream of the Oglio confluence (Figure 4).

Diversity in the Po tended to decrease in the downstream direction in both seasons (Figures 4 and 6). This pattern, together with the clear downstream dominance of planktonic taxa (Figure 7), might be ascribed to the progressive longitudinal decrease in turbulence, resulting in a reduction of re-suspension of organisms from the bottom and more favourable conditions for the development of a truly planktonic community (Zhou et al., 2008). This was especially evident in summer, when halved average current speeds, higher temperatures and primary production, and lower turbulence and turbidity provided suitable conditions for the development of a truly potamal zooplankton assemblage in the main channel (Figures 3, 5 and 6).

The observed summer dominance of brachionid rotifers is a common pattern in large rivers, thanks to the generally better ability of these loricate taxa to feed and grow in the current when compared to illoricate rotifers (Lair, 2006; Zimmermann-Timm et al., 2007). Accordingly, the gradual downstream increase in abundance of most Brachionus and Keratella species, and the parallel increase in density of large brachionid subitaneous eggs, suggest that in summer, with current speeds between 0.40 and $0.74 \mathrm{~m} \mathrm{~s}^{-1}$, water residence time was long enough to allow growth and reproduction of fast-growing rotifers in the main stream, although Rzoska (1978) reported that zooplankton reproduction in rivers is rarely observed at flow velocities over $0.4 \mathrm{~m} \mathrm{~s}^{-1}$. The role of tributaries as organism inocula was most likely negligible in this case, as the dominant brachionids in the Po showed markedly lower densities in all major tributaries in summer (Figures 5 and 6).

While the MIN river had no apparent influence on the Po river rotifer assemblage under summer low-flow conditions, it acted as a significant inoculum of microcrustaceans (Figure 6). The latter, however, do not seem able to sustain high population abundances once they enter the Po river, likely because of their longer development time, higher susceptibility to physical damage during downstream transport and higher vulnerability of their feeding apparati to suspended solids compared to rotifers (Kirk and Gilbert, 1990; Jack et al., 1993; Sluss et al., 2008).

The unexpected abrupt decrease in density observed in summer at the most downstream Po river station for several dominant rotifer taxa (Figures 5 and 6) might be ascribed to a combination of different factors. Water velocity was negligible at this site (Bertani, pers. comm.), thereby enhancing sinking of non-motile diatoms. This is further supported by the observed decrease in SPM (Figure 3), and it might explain the marked decline in Chl- $a$ when coupled with the downstream decrease in DRSi (Figure 3). The reduction in available resources may thus have contributed to the observed drop in zooplankton abundance.
Predation by Asplanchna may also play a role in shaping the rotifer assemblage in the lower segment of the Po, as suggested by the exponential increase in Asplanchna densities in coincidence with the decrease in most rotifer taxa (Figure 5). Previous studies on gut contents of $A$. brightwellii in the Po confirmed that rotifers made up the largest proportion of the predator's diet (Bertani et al., 2012, 2013). Asplanchna was also shown to induce antipredator morphological changes in B. calyciflorus in the river (Bertani et al., 2013). Accordingly, we observed a sharp increase in the spined morphotype paralleled by a decrease in the unspined one in coincidence with the appearance of Asplanchna in the lower river trait (Figure 5). Moreover, the peak in Brachionus resting egg production observed just upstream of SER_12 suggests that density-dependent selfregulation mechanisms in response to crowding might have also contributed to the observed decline in large dominant brachionids (Gilbert, 2003). Finally, a higher grazing pressure from benthic molluscs can also be hypothesized (Hardenbicker et al., 2015), as suggested by the peak of veliger density found in the lower section of the river.

\section{CONCLUSIONS}

The Po river and its main tributaries showed high inorganic nutrient levels that are mainly attributable to intensive agricultural and industrial activities in the river basin.

The hydrodynamic model used in this study proved to be capable of simulating Po river flow with a sufficient degree of accuracy to support the design of Lagrangian surveys. This allowed us to directly examine the large-scale longitudinal variability in hydrochemistry and zooplankton community structure during downstream transport in the Po river, including the relative contribution of the major tributaries.

Different seasonal and hydrological conditions resulted in markedly distinct longitudinal patterns in some of the physico-chemical variables and especially in the downstream development of phytoplankton (as determined by Chl-a) and zooplankton abundance and composition. In spring, relatively high discharge rates and corresponding low water residence times, coupled with low water temperatures, prevented plankton growth in the main channel. Under summer low flow rates, higher temperatures and a decrease in turbulence and turbidity associated with longer residence times stimulated algal growth and in-stream reproduction of fast-growing rotifer taxa. The importance of biotic interactions within the zooplankton (bottom-up, topdown and self-regulation mechanisms) in driving community abundance and composition may also increase in the downstream direction, as the impact of physical forcings decreases. The extremely high zooplankton densities found 
in a severely dammed tributary highlight the impact that anthropogenic alterations of river hydrology can exert on biological communities, with potential repercussions in the downstream systems.

\section{ACKNOWLEDGEMENTS}

Pierluigi Viaroli (University of Parma) provided all the necessary laboratory materials and facilities for hydrochemical analyses and gave helpful comments on an early version of this manuscript. Alberto Agnetti (Hydro-Meteo-Climate Service, ARPA Emilia-Romagna) helped in performing the model simulations on which the Lagrangian surveys were based. IB and GR acknowledge the support of the LifeWatch network. The authors also thank anonymous reviewers for their helpful and constructive comments.

\section{CONFLICT OF INTEREST}

The authors declare that they have no conflict of interest.

\section{REFERENCES}

Alonso M. 1996. Crustacea, Branchiopoda. Fauna Ibérica, vol. 7. Museo Nacional de Ciencias Naturales, CSIS: Madrid.

American Public Health Association, American Water Works Association, Water Environment Federation. 1998. Standard Methods for the Examination of Water and Wastewater, 20th edn. American Public Health Association: Washington DC.

Anderson MJ. 2001. A new method for non-parametric multivariate analysis of variance. Austral Ecology 26: 32-46.

Bertani I, Ferrari I, Rossetti G. 2012. Role of intra-community biotic interactions in structuring riverine zooplankton under low-flow, summer conditions. Journal of Plankton Research 34: 308-320.

Bertani I, Leonardi S, Rossetti G. 2013. Antipredator-induced trait changes in Brachionus and prey selectivity by Asplanchna in a large river under low-discharge conditions: evidence from a field study. Hydrobiologia 702: 227-239.

Bertani I, Del Longo M, Pecora S, Rossetti G. 2014. Longitudinal dynamics of river zooplankton during downstream transport: a Lagrangian sampling approach. Atti dei Convegni Lincei 279: 251-258.

Braioni MG, Gelmini D. 1983. Rotiferi Monogononti (Rotatoria: Monogononta). Consiglio Nazionale delle Ricerche AQ/1/200: Roma.

Brown JB, Battaglin WA, Zuellig RE. 2009. Lagrangian sampling for emerging contaminants through an urban stream corridor in Colorado. Journal of the American Water Resources Association 45: 68-82.

Casper AF, Thorp JH. 2007. Diel and lateral patterns of zooplankton distribution in the St. Lawrence River. River Research and Applications 23: 73-85.

Coupe RH, Goolsby DA, Battaglin WA, Böhlke JK, McMahon PB, Kendall C. 2013. Transport of nitrate in the Mississippi River in July-August 1999. Annals of Environmental Science 7: 31-46.

De Leo GA, Ferrari I. 1993. Disturbance and diversity in a river zooplankton community: a neutral model analysis. Coenoses 8: 121-129.

De Smet WH. 1996. Rotifera. Vol. 4: The Proalidae (Monogononta). SPB Academic Publishing: Amsterdam.

De Smet WH, Gibson JAE. 2008. Rhinoglena kutikovae n.sp. (Rotifera: Monogononta: Epiphanidae) from the Bunger Hills, East Antarctica: a probable relict species that survived Quaternary glaciations on the continent. Polar Biology 31: 595-603.

De Smet WH, Pourriot R. 1997. Rotifera. Vol. 5: The Dicranophoridae (Monogononta). SPB Academic Publishing: Amsterdam.

Deutsch B, Voss M, Fischer H. 2009. Nitrogen transformation processes in the Elbe River: distinguishing between assimilation and denitrification by means of stable isotope ratios in nitrate. Aquatic Sciences 71: 228-237.

Doyle MW, Ensign SH. 2009. Alternative reference frames in river system science. BioScience 59: 499-510.

Dussart BH. 1969. Les Copépodes des eaux continentales d'Europe occidentale. 1. Calanöides et Harpacticöides; 2. Cyclopöides et Biologie. Boubée \& Cie: Paris.

Dussart BH, Defaye D. 1995. Copepoda: Introduction to the Copepoda. SPB Academic Publishing: Amsterdam.

Einsle U. 1996. Copepoda: Cyclopoida. Genera Cyclops, Megacyclops, Acanthocyclops. SPB Academic Publishing: Amsterdam.

Gilbert JJ. 2003. Specificity of crowding response that induces sexuality in the rotifer Brachionus. Limnology and Oceanography 48: 1297-1303.

Golterman HL, Clymo RS, Ohnstand MAM. 1978. Methods for Physical and Chemical Analysis of Freshwaters, IBP Handbook No. 8. Blackwell Science: Oxford.

Gruberts D, Paidere J. 2014. Lagrangian drift experiment on the Middle Daugava River (Latvia) during the filling phase of the spring floods. Fundamental and Applied Limnology 184: 211-230.

Gruberts D, Paidere J, Škute A, Druvietis I. 2012. Lagrangian drift experiment on a large lowland river during a spring flood. Fundamental and Applied Limnology 179: 235-249.

Guhr H, Spott D, Bormki G, Baborowski M, Karrasch B. 2003. The effects of nutrient concentrations in the River Elbe. Acta Hydrochimica et Hydrobiologica 31: 282-296.

Gurney R. 1933. British Fresh-Water Copepoda, Vol. 3. Cyclopoida. Adlard and Son: London.

Hammer $\varnothing$, Harper DAT, Ryan PD. 2001. PAST: paleontological statistics software package for education and data analysis. Palaeontologia Electronica 4: 9.

Hardenbicker P, Weitere M, Ritz S, Schöll F, Fischer H. 2015. Longitudinal plankton dynamics in the rivers Rhine and Elbe. River Research and Applications DOI: 10.1002/rra.2977 (in press).

Ietswaart T, Breebaart L, van Zanten B, Bijker R. 1999. Plankton dynamics in the river Rhine during downstream transport as influenced by biotic interactions and hydrological conditions. Hydrobiologia 410: $1-10$.

Jack JD, Wickham SA, Toalson S, Gilbert JJ. 1993. The effects of clays on a freshwater plankton community: an enclosure experiment. Archiv für Hydrobiologie 127: 257-270.

Karaytug S. 1999. Copepoda: Cyclopoida. Genera Paracyclops, Ochridacyclops and Key to the Eucyclopinae. Backhuys Publishers: Leiden.

Kiefer F. 1968. Versuch einer Revision der Gattung Eudiaptomus Kiefer (Copepoda Calanoida). Memorie Istituto Italiano Idrobiologia 24: 9-160.

Kirk KL, Gilbert JJ. 1990. Suspended clay and the population dynamics of planktonic rotifers and cladocerans. Ecology 71: 1741-1755.

Koste W. 1978. Rotatoria. Gebrüder Borntraeger: Berlin.

Lair N. 2006. A review of regulation mechanisms of metazoan plankton in riverine ecosystems: aquatic habitat versus biota. River Research and Applications 22: 567-593.

Legendre P, Legendre L. 1998. Numerical Ecology, 2nd edn. Elsevier Science B.V: Amsterdam.

Margaritora FG. 1985. Cladocera. Fauna d'Italia. Calderini: Bologna.

Napiórkowski P, Napiórkowska T. 2013. The diversity and longitudinal changes of zooplankton in the lower course of a large, regulated European river (the lower Vistula River, Poland). Biologia 6: 1163-1171. 
Nogrady T, Pourriot R, Segers H. 1995. Rotifera. Vol. 3: The Notommatidae and The Scaridiidae. SPB Academic Publishing: Amsterdam.

Oksanen J, Blanchet FG, Kindt R, Legendre P, Minchin PR, O'Hara RB, Simpson GL, Solymos P, Henry M, Stevens H, Wagner H. 2015. vegan: Community Ecology Package. R package version 2.3-0. https://cran.rproject.org/web/packages/vegan/. Accessed 21 March 2016.

Quiel K, Becker A, Kirchesch V, Schöl A, Fischer H. 2011. Influence of global change on phytoplankton and nutrient cycling in the Elbe River. Regional Environmental Change 11: 405-421.

R Core Team 2015. R: a language and environment for statistical computing. R Foundation for Statistical Computing, Vienna, Austria. URL http://www.R-project.org/. Accessed 21 March 2016.

Reckendorfer W, Keckeis H, Winkler G, Schiemer F. 1999. Zooplankton abundance in the River Danube, Austria: the significance of inshore retention. Freshwater Biology 41: 583-591.

Ricciardi G, Montani A, Paccagnella T, Pecora S, Tonelli F. 2013. Forecasting skills of the ensemble hydro-meteorological system for the Po river floods. EGU General Assembly Conference Abstracts 15: 7227.

Rodier J. 1978. L'analyse de l'eau. Dunod: Orleans.

Rossetti G, Viaroli P, Ferrari I. 2009. Role of abiotic and biotic factors in structuring the metazoan plankton community in a lowland river. River Research and Applications 25: 814-835.

Ruttner-Kolisko A. 1974. Planktonic Rotifers: Biology and Taxonomy Die Binnengewässer (Suppl.) 26. Schweizerbart: Stuttgart.

de Ruyter van Steveninck ED, Admiraal W, Breebaart L, Tubbing GMJ, van Zanten B. 1992. Plankton in the River Rhine: structural and functional changes observed during downstream transport. Journal of Plankton Research 14: 1351-1368.

Rzoska J. 1978. On the Nature of Rivers. Dr. W. Junk: The Hague.

Scherwass A, Bergfeld T, Schöl A, Weitere M, Arndt H. 2010. Changes in the plankton community along the length of the River Rhine: Lagrangian sampling during a spring situation. Journal of Plankton Research 32: 491-502.

Schiemer F, Keckeis H, Reckendorfer W, Winkler G. 2001. The "inshore retention concept" and its significance for large rivers. Archiv für Hydrobiologie, Supp. 135. Large Rivers 12: 509-516.

Segers H. 1994. Redescription of Lecane fadeevi (Neiswestnowa-Shadina, 1935) (Rotifera, Lecanidae). Bulletin de l'Institut Royal de Sciences Naturelles de Belgique, Biologie 64: 235-238.

Segers H. 1995a. Rotifera. Vol. 2: The Lecanidae (Monogononta). SPB Academic Publishing: Amsterdam.

Segers H. 1995b. A reappraisal of the Scaridiidae (Rotifera, Monogononta). Zoologica Scripta 24: 91-100.

Segers H, Sarma SSS, Ovie SI, Mbogo DK. 1994. Note on the taxonomy and distribution of Brachionus durgae Dhanapathi, 1974 (Rotifera: Brachionidae). Journal of African Zoology 108: 397-400.
Sluss TD, Cobbs GA, Thorp JH. 2008. Impact of turbulence on riverine zooplankton: a mesocosm experiment. Freshwater Biology 53: 1999-2010.

Syvitski JPM, Kettner AJ. 2007. On the flux of water and sediment into the Northern Adriatic Sea. Continental Shelf Research 27: 296-308.

Tavernini S, Pierobon E, Viaroli P. 2011. Physical factors and dissolved reactive silica affect phytoplankton community structure and dynamics in a lowland eutrophic river (Po river, Italy). Hydrobiologia 669: 213-225.

Ueda H, Reid JW. 2003. Copepoda: Cyclopoida. Genera Mesocyclops and Thermocyclops. Backhuys Publishers: Leiden.

Valderrama JC. 1977. Methods used by the hydrographical department of the National Board of Fisheries. In Report of the Baltic Intercalibration Workshop. Annex, Interim Commission for the Protection of the Environment of the Baltic Sea, Grasshof K (ed). Goteborg: Sweden; 13-40.

Vezzoli R, Pecora S, Manzi M-P. 2013 Using a weather generator to simulate daily precipitation scenarios from seasonal weather forecasts. CMCC Research Paper No. 176, 9 pp.

Viaroli P, Bartoli M, Castaldelli G, Naldi M, Nizzoli D, Rossetti G. 2013a. Recent evolution and expected changes of nutrient loads in a heavily exploited watershed: the Po River, Italy. IASH Publication 361: 175-182.

Viaroli P, Nizzoli D, Pinardi M, Rossetti G, Bartoli M. 2013b. Factors affecting dissolved silica concentrations, and DSi and DIN stoichiometry in a human impacted watershed (Po river, Italy). Silicon 5: 101-114.

Volkmar EC, Dahlgren RA, Stringfellow WT, Henson SS, Borglin SE, Kendall C, Van Nieuwenhuyse EE. 2011. Using Lagrangian sampling to study water quality during downstream transport in the San Luis Drain, California, USA. Chemical Geology 283: 68-77.

Weitere M, Arndt H. 2003. Structure of the heterotrophic flagellate community in the water column of the River Rhine (Germany). European Journal of Protistology 39: 287-300.

Welker M, Walz N. 1998. Can mussels control the plankton in rivers?-a planktological approach applying a Lagrangian sampling strategy. Limnology and Oceanography 43: 753-762.

Writer JH, Keefe SK, Ryan JN, Ferrer I, Thurman ME, Barber LB. 2011. Methods for evaluating in-stream attenuation of trace organic compounds. Applied Geochemistry 26: S344-S345.

Zanchettin D, Traverso P, Tomasino M. 2008. Po River discharges: a preliminary analysis of a 200-year time series. Climatic Change 89: 411-433.

Zhou S, Tang T, Wu N, Fu X, Cai Q. 2008. Impact of a small dam on riverine zooplankton. International Review of Hydrobiology 93: 297-311.

Zimmermann-Timm H, Holst H, Kausch H. 2007. Spatial dynamics of rotifers in a large lowland river, the Elbe, Germany: how important are retentive shoreline habitats for the plankton community? Hydrobiologia 593: 49-58. 